\title{
Short-term competence in larvae of queen conch Strombus gigas: shifts in behavior, morphology and metamorphic response
}

\author{
Megan Davis \\ Caribbean Marine Research Center, 805 E. 46th Place, Vero Beach, Florida 32963, USA
}

\begin{abstract}
Competent larvae of the prosobranch gastropod Strombus gigas Linne (queen conch) require an environmental cue to induce metamorphosis. In this laboratory investigation the planktotrophic veligers of $S$. gigas were exposed to 2 cues to observe changes in metamorphic response as a function of age. The cues were extract of Laurencia poitei, an artificial cue, and detrital blades of Thalassia testudinum, a natural cue. Onset of competence began $18 \mathrm{~d}$ post-hatch, and veligers were competent for only $6 \mathrm{~d}$ at 28 to $30^{\circ} \mathrm{C}$. Both cues induced the highest percentage metamorphosis on Day 23 (88\% for extract and $78 \%$ for detritus), and response dropped dramatically by Day 25 (3\% for extract and $15 \%$ for detritus). Shell length for successful metamorphosis ranged between 952 and $1258 \mu \mathrm{m}$. Pigmentation change from orange to dark green on the propodium and larval operculum indicated competence, and competent veligers exhibited a swim-crawl behavior associated with settlement. This study revealed that veligers of $S$. gigas have a unique developmental history. The competence period was shorter than the precompetence period. Most other planktotrophic larvae are competent for a time equal to or longer than the precompetence period. Short-term competence is ordinarily associated with metamorphosis to a broad spectrum of cues. This may explain why veligers of $S$. gigas were observed to metamorphose to a variety of benthic cues found in juvenile conch seagrass habitats.
\end{abstract}

KEY WORDS: Artificial cue C Competence - Gastropod - Metamorphosis · Natural cue · Strombus gigas

\section{INTRODUCTION}

Marine invertebrate larvae undergo a period of growth and differentiation during a precompetence period (Crisp 1974, Hadfield 1978, Pechenik 1985), and for many species temperature, salinity, and larval nutrition influence the duration of this period (Hadfield 1977, Pechenik 1984, Pechenik \& Lima 1984, Zimmerman \& Pechenik 1991). At competence the larvae are morphologically and physiologically capable of undergoing metamorphosis, usually in the presence of an environmental cue associated with juvenile or adult habitats (Crisp 1974, Scheltema 1974, Pechenik 1980, Burke 1983, Pawlik 1992). Larvae which disperse great distances and those which need specialized metamorphic cues seem to have a greater capacity for delaying metamorphosis, by having long periods during which they maintain competence (Scheltema 1971, Jackson \& Strathmann 1981, Pechenik 1984). Larvae which have relatively short competence periods are probably associated with broader metamorphic cue and benthic habitat requirements (Pechenik 1984); therefore, they must metamorphose in a narrow window of time, metamorphose spontaneously, or lose the ability to metamorphose causing the larvae to die (Pechenik 1990). Short-term competence is usually associated with lecithotrophic larvae, because these non-feeding larvae need to metamorphose before they become nutritionally stressed and die (Jackson \& Strathmann 1981, Pechenik et al. 1993).

The planktotrophic larvae (veliger) of the prosobranch gastropod Strombus gigas Linne (queen conch) may also have a short competence period (Davis et al. 1987, Mianmanus 1988). The purpose of this laboratory study was to determine onset and duration of competence for larvae of $S$. gigas raised under uniform and optimum conditions (i.e. temperature, salinity, nutrition) that may mimic the field environment (Davis 
1993). Conch veligers need a cue to initiate metamorphosis (Mianmanus 1988, Davis et al. 1990, M. Davis \& A. W. Stoner unpubl.); therefore, to observe changes in metamorphic response as a function of age the veligers were exposed to an artificial and natural cue. Both cues were investigated because some larval species become responsive to artificial cues before they become responsive to natural cues (Coon et al. 1990, Pechenik \& Gee 1993). The artificial cue was an aqueous extract of the red macroalga Laurencia poitei, which is used routinely in conch hatcheries to induce a reliable metamorphosis (Mianmanus 1988, Davis et al. 1990). This extract contains an inducing pigment, R-phycoerythrin, which is similar to the artificial neurotransmitter inducer, $\gamma$-amino butyric acid (GABA) (Morse et al. 1979). The natural cue was detritus (senescent blades) from the seagrass Thalassia testudinum. These blades are associated with juvenile conch seagrass habitats and are known to induce metamorphosis of competent conch larvae (M. Davis \& A. W. Stoner unpubl.). Shifts in morphological differentiation, size, and behavior as a function of age were also evaluated as indicators of competence for larvae of S. gigas.

\section{MATERIALS AND METHODS}

General protocol. Laboratory experiments were conducted at the Caicos Conch Farm, Providenciales, Turks and Caicos Islands, from 22 July to 3 August 1992. This production-oriented mariculture facility cultures juveniles of Strombus gigas. Larval development has been described by D'Asaro (1965) and techniques for culturing larvae of $S$. gigas in a hatchery system were outlined by Davis (1993).

Larvae chosen for this study were from 1 hatchery culture (\#125) comprised of 3 spawns from 3 females. This provided veligers with genetic variation. Nearcompetent veligers were cultured in the hatchery at $20 \mathrm{I}^{-1}$ and raised using routine procedures which included complete change of water every $48 \mathrm{~h}$, continuous flow of seawater ( $\left.1 \mathrm{l} \mathrm{min}^{-1}\right)$, and daily feeding of phytoplankton (Caicos Isochrysis and Chaetoceros gracilis) (Davis 1993). Larvae used in these experiments were homogeneous in size and development because slow-growers were screened during water changes. In laboratory culture, conch veligers become competent between 18 and $26 \mathrm{~d}$ after hatch (Laughlin \& Weil 1983, Siddall 1983, Davis et al. 1990). Therefore, experiments began with precompetent veligers (16 d post-hatch), and ended when fewer than 15\% were induced to metamorphose.

Experimental treatments were conducted in white, flat-bottom polyethylene containers $(5.5 \mathrm{~cm}$ height $\times$
$10.5 \mathrm{~cm}$ diameter). A $0.10 \%$ chlorine bleach solution was used to disinfect the containers before and between experiments. Each treatment used $300 \mathrm{ml}$ of filtered $(10 \mu \mathrm{m})$ seawater and experiments were performed in static water. The seawater temperature was 28 to $30^{\circ} \mathrm{C}$, salinity was 36 to $39 \mathrm{ppt}$, and photoperiod was approximately $12 \mathrm{~h}$ light: $12 \mathrm{~h}$ dark.

Analysis of variance (ANOVA) was used following the guidelines of Day \& Quinn (1989). Cochran's test was used to test for homogeneity of variances. The data were homogeneous ( $p>0.05$ ); therefore, ANOVAs were performed with untransformed proportional data, followed by Tukey's multiple comparison test.

Metamorphosis as a function of age. Both an artificial (extract of Laurencia poitei) and natural cue (detrital blades of Thalassia testudinum) were used to test for metamorphic competence. Techniques for preparing an aqueous extract of $L$. poitei were outlined in Davis et al. (1990). Laurencia poitei was collected from a shallow seagrass habitat, fronds were blended with seawater (1:2 ratio), frozen to lyse the cells, and defrosted and screened ( $75 \mu \mathrm{m}$ mesh) to produce the finished extract ( $10 \mathrm{~g}$ wet $w \mathrm{t}$ algal fronds $\mathrm{l}^{-1}$ seawater), which was frozen then defrosted on each experimental date.

Detrital blades were collected on each experimental day from a shallow seagrass habitat approximately $500 \mathrm{~m}$ offshore from the hatchery. In the laboratory, the blades were gently rinsed with seawater to remove sediment but retain epiphytes (bacteria, diatoms, and filamentous macroalgae) which are the main metamorphic inducing component (M. Davis \& A. W. Stoner unpubl.). Detrital blades ( $3.0 \mathrm{~g} \pm 0.2, \mathrm{SD})$ were placed in each of the seawater-filled treatment containers. Seawater controls were used to record spontaneous metamorphosis. There is no gregarious settlement effect when using multiple larvae of Strombus gigas in a treatment container (M. Davis \& A. W. Stoner unpubl.); therefore, each treatment and control had 6 replicates with 25 larvae per replicate $\left(83 \mathrm{l}^{-1}\right)$.

Subsamples from the culture were taken at 2 to $3 \mathrm{~d}$ intervals $(16,18,20,23$, and $25 \mathrm{~d}$ post-hatch) to determine onset and duration of competence. On each experimental day approximately 1000 larvae were siphoned from the culture onto a $400 \mu \mathrm{m}$ mesh sieve, and then rinsed into a shallow bowl. Actively swimming larvae with extended velar lobes were pipetted into the containers to avoid dead, damaged, or metamorphosed animals. Larvae were exposed to the extract cue for only $5 \mathrm{~h}$ to avoid toxicity to the larvae, then were rinsed with seawater before being placed into seawater-filled containers for the remaining $24 \mathrm{~h}$ (Mianmanus 1988, Davis et al. 1990). Larvae were exposed to the detritus cue and seawater controls for $24 \mathrm{~h}$. There is no difference in percentage meta- 
morphosis after 24 and $48 \mathrm{~h}$ (1-way ANOVA, $F_{1,18}=$ $0.81, p=0.381$ ) (M. Davis \& A. W. Stoner unpubl.); therefore, percentage metamorphosis was recorded after $24 \mathrm{~h}$ by observing all 25 individuals from each treatment container with the aid of a dissecting microscope $(20 \times)$. Metamorphosis of $S$. gigas is recognized when the velar lobes are lost, the juvenile conch are crawling with their propodium, and they are searching for food with the proboscis (Brownell 1977, Davis et al. 1990)

Morphology as a function of age. Morphological differentiation and shell length were also examined on the days outlined above. Twenty larvae were randomly removed from the culture and observed using the dissecting microscope $(40 \times)$ for morphological changes (i.e. propodium pigmentation, larval and adult opercula, velar lobes, and shell pigmentation). Twenty larvae were also preserved in $5 \%$ buffered formalin $(\mathrm{pH} 8.0)$ to be measured for shell length (apex to siphonal canal) with the aid of a dissecting microscope $(20 \times)$ equipped with an ocular micrometer.

After veligers were exposed to extract of Laurencia poitei for $5 \mathrm{~h}$, up to 20 larvae and 20 newly metamorphosed juveniles were preserved to be measured for differences in shell length. Individuals from the extract were chosen for measurements because there was no food present in these containers. The detritus cue had epiphytic diatoms available as food for the newly metamorphosed juveniles and may have generated growth differences between the larvae and juveniles.

Behavior as a function of age. Swimming behavior was observed on the days outlined above for larvae in seawater controls and in low extract doses of Laurencia poitei. This low extract concentration of L. poitei (1.0 g wet wt algal fronds $\mathrm{l}^{-1}$ seawater) is known to elicit a settlement response, but not necessarily cause metamorphosis (M. Davis \& A. W. Stoner unpubl.). Individual larvae were placed in each of the 20 containers of seawater and extract for approximately $24 \mathrm{~h}$. Cultures were examined after $5 \mathrm{~h}$ in the evening (18:00 to $20: 00 \mathrm{~h}$ ) and after $21 \mathrm{~h}$ late the following morning (10:00 to $12: 00 \mathrm{~h})$. During each of the observation periods individual larvae were viewed for several seconds and location of larvae in the container (top or bottom), swimming patterns (twirling, bouncing, stationary, and swim-crawl), and metamorphosis were recorded. Twirling was defined as a larva rotating in one place; bouncing was an up-and-down motion of the larvae at the water surface; and a larva was stationary when its lobes were extended with only ciliary motion. Swim-crawl behavior occurred when a larva used its propodium to move over the container surface with its lobes still extended.

\section{RESULTS}

\section{Induction of metamorphosis}

On Day 16, larvae did not metamorphose in response to the natural seagrass detritus cue, but did metamorphose in response to the artificial extract cue $(33 \%)$. However, these metamorphosed conch had emaciated bodies and were inactive, whereas larvae that metamorphosed in response to both cues on Days 18 to 25 had tissue-filled shells and were active (i.e. searching for food with the proboscis and gliding with the propodium)

Metamorphic response to extract was high and similar from Day 18 to 23 ( 76 to $88 \%$ ), but the response to detritus increased gradually from Day 18 to 23 (21 to $78 \%$ ) (Fig. 1). Because larvae of different ages responded differently to the 2 cues over time there was a significant Inducer $\times$ Age interaction (Table 1, Fig. 1). Metamorphic

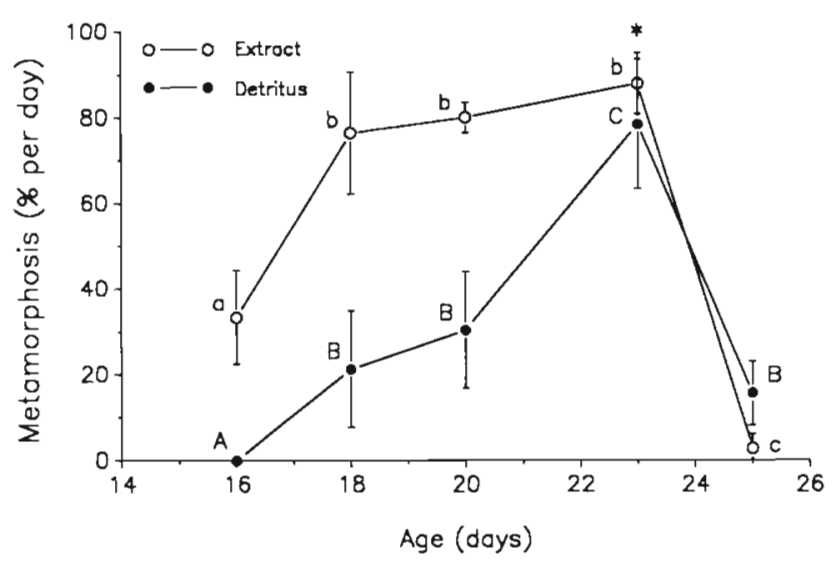

Fig. 1. Strombus gigas. Metamorphic response as a function of age for larvae exposed to artificial inducer (extract of Laurencia poitei) and natural inducer (detrital blades of Thalassia testudinum). Asterisk indicates similar metamorphic responses for larvae exposed to the 2 cues on Day 23; all other responses are significantly different $(p<0.01)$. Letters designate similar means for larvae of different ages exposed to extract (lower case) and detritus (upper case) (Tukey's multiple comparison test of means). $\mathrm{n}=25$ larvae per treatment, with 6 replicates per treatment

Table 1. Strombus gigas. Results of 2-way analysis of variance testing for differences in metamorphic inductive potential of extract of Laurencia poitei and detrital blades of Thalassia testudinum. Age represents the number of days after hatch

\begin{tabular}{|lrrrc|}
\hline Source & df & MS & $F$ & $p$ \\
\hline Inducer $\times$ Age & 4 & 0.243 & 23.12 & $<0.01$ \\
Inducer & 1 & 1.091 & 103.78 & $<0.01$ \\
Age & 4 & 1.091 & 103.80 & $<0.01$ \\
Error & 50 & 0.011 & & \\
\hline
\end{tabular}


responses were significantly different for larvae exposed to extract and detritus on Days 16, 18, 20, and $25(p<0.01)$. However, on Day 23, percentage metamorphosis was the highest and not statistically different for larvae in the 2 cues $188 \%$ for extract and $78 \%$ for detritus; 1 -way ANOVA, $\left.F_{1,10}=1.92, \mathrm{p}=0.196\right)$. By Day 25 , percentage metamorphosis decreased dramatically ( $3 \%$ for extract and $15 \%$ for detritus). Spontaneous metamorphosis did not occur in seawater controls.

\section{Morphological changes}

On Day 16, precompetent veligers had orange pigmentation on the larval operculum and propodium. Competent veligers (Days 18 to 23) showed various development of the adult operculum and an increase in green pigmentation on the propodium and larval operculum (Table 2). By Day 25, the body and shell of postcompetent larvae were heavily pigmented with white blotches, the foot was totally covered in green pigment, and the velar lobes had decreased in size.

Larvae exposed to extract of Laurencia poitei metamorphosed at a mean shell length of $1125 \pm 71 \mu \mathrm{m}$ with a minimum size for successful metamorphosis of $952 \mu \mathrm{m}$, and a terminal larval shell size of $1258 \mu \mathrm{m}$. Measurements of larvae prior to exposure to extract showed that size changed with age (1-way ANOVA, $F_{4,95}=26.63$, $\mathrm{p}<0.001$ ), shell length increased from Day 16 (precompetent veligers) to Day 18 (competent veligers), but did not increase after Day 18 (Table 3). Differences in shell lengths occurred between the newly metamorphosed juveniles and larvae which were removed from the extract after 5 h of exposure (Table 3 ). As predicted, Day 16 and 18 juveniles were larger than larvae of the same age. On Days 20 and 23, juveniles and larvae were similar in size. By Day 25, the larvae had longer shells than the juveniles; however, this could be an artifact considering the low sample size $(n=4)$ for the metamorphosed juvenile shells (Table 3 ).
Table 2. Strombus gigas. Development of the propodium, operculum, and other key characteristics during the precompetent, competent, and postcompetent periods of larvae. Larvae were induced to metamorphose by an artificial cue (extract of Laurencia poitei) and a natural cue (detrital blades of Thalassia testudium). Refer to D'Asaro (1965) for diagrams and further morphological descriptions

\begin{tabular}{|c|c|c|}
\hline Age (d) & Developmental changes & Period \\
\hline 16 & $\begin{array}{l}\text { Conchiolin claw of adult } \\
\text { operculum extended over } \\
\text { the pigments larval oper- } \\
\text { culum. Orange on the foot }\end{array}$ & Precompetence \\
\hline 18 & $\begin{array}{l}\text { Dark green pigmentation } \\
\text { appears on the propodium }\end{array}$ & Competence \\
\hline 20 & $\begin{array}{l}\text { Propodium pigments com- } \\
\text { pletely green. Larval oper- } \\
\text { culum pigments green, and } \\
\text { border and interior pigments } \\
\text { orange }\end{array}$ & Competence \\
\hline 23 & $\begin{array}{l}\text { Larval operculum completely } \\
\text { green. Adult operculum } \\
\text { widens. Tentacles and body } \\
\text { pigments green }\end{array}$ & Competence \\
\hline 25 & $\begin{array}{l}\text { Larval operculum decreases } \\
\text { in size and the adult oper- } \\
\text { culum continues to expand. } \\
\text { Shell pigments white and } \\
\text { beige. Velar lobes decrease } \\
\text { in length }\end{array}$ & $\begin{array}{l}\text { Loss of } \\
\text { competence }\end{array}$ \\
\hline
\end{tabular}

\section{Behavior patterns}

Larval swimming behavior changed with age. Younger larvae (Days 16 to 20) spent more time in the upper water column than the older larvae (Days 23 to 25) which were observed near the bottom of the container (Fig. 2). A low percentage of larvae were observed in the swim-crawl stage throughout the experiment (Days 16 to 25). However, the percentage of larvae in the swim-crawl stage was highest on Day 23 (Fig. 2) which corresponds to the high per-

Table 3. Strombus gigas. Shell lengths of larvae before and after exposure to extract of Laurencia poitei, and newly metamorphosed juveniles. Values are mean $\pm \mathrm{SD}(\mathrm{n})$ in $\mu \mathrm{m}$. One-way ANOVA result are shown for differences in shell lengths between the larvae and newly metamorphosed juveniles which were removed from extract of $L$. poitei after $5 \mathrm{~h}$ of exposure. ns: not significant

\begin{tabular}{|c|c|c|c|c|c|}
\hline \multirow[t]{2}{*}{ Age (d) } & \multirow{2}{*}{$\begin{array}{l}\text { Shell lengths of } \\
\text { unexposed larvae }\end{array}$} & \multicolumn{2}{|c|}{ Shell lengths after exposure } & \multicolumn{2}{|c|}{ ANOVA } \\
\hline & & $\begin{array}{c}\text { Larvae } \\
\text { (no metamorphosis) }\end{array}$ & $\begin{array}{c}\text { Juveniles } \\
\text { (metamorphosis) }\end{array}$ & $F$ & $\mathrm{p}$ \\
\hline 16 & $969 \pm 86(20)$ & $989 \pm 80(20)$ & $1078 \pm 52(20)$ & 17.13 & $<0.01$ \\
\hline 18 & $1088 \pm 60(20)$ & $1015 \pm 69(20)$ & $1095 \pm 62(20)$ & 14.81 & $<0.01$ \\
\hline 20 & $1180 \pm 55(20)$ & $1171 \pm 61(20)$ & $1175 \pm 36(20)$ & 0.046 & ns \\
\hline 23 & $1154 \pm 67(20)$ & $1149 \pm 96(15)$ & $1170 \pm 64(20)$ & 0.568 & ns \\
\hline 25 & $1125 \pm 84(20)$ & $1159 \pm 72(20)$ & $1046 \pm 75(4)$ & 8.185 & $<0.01$ \\
\hline
\end{tabular}



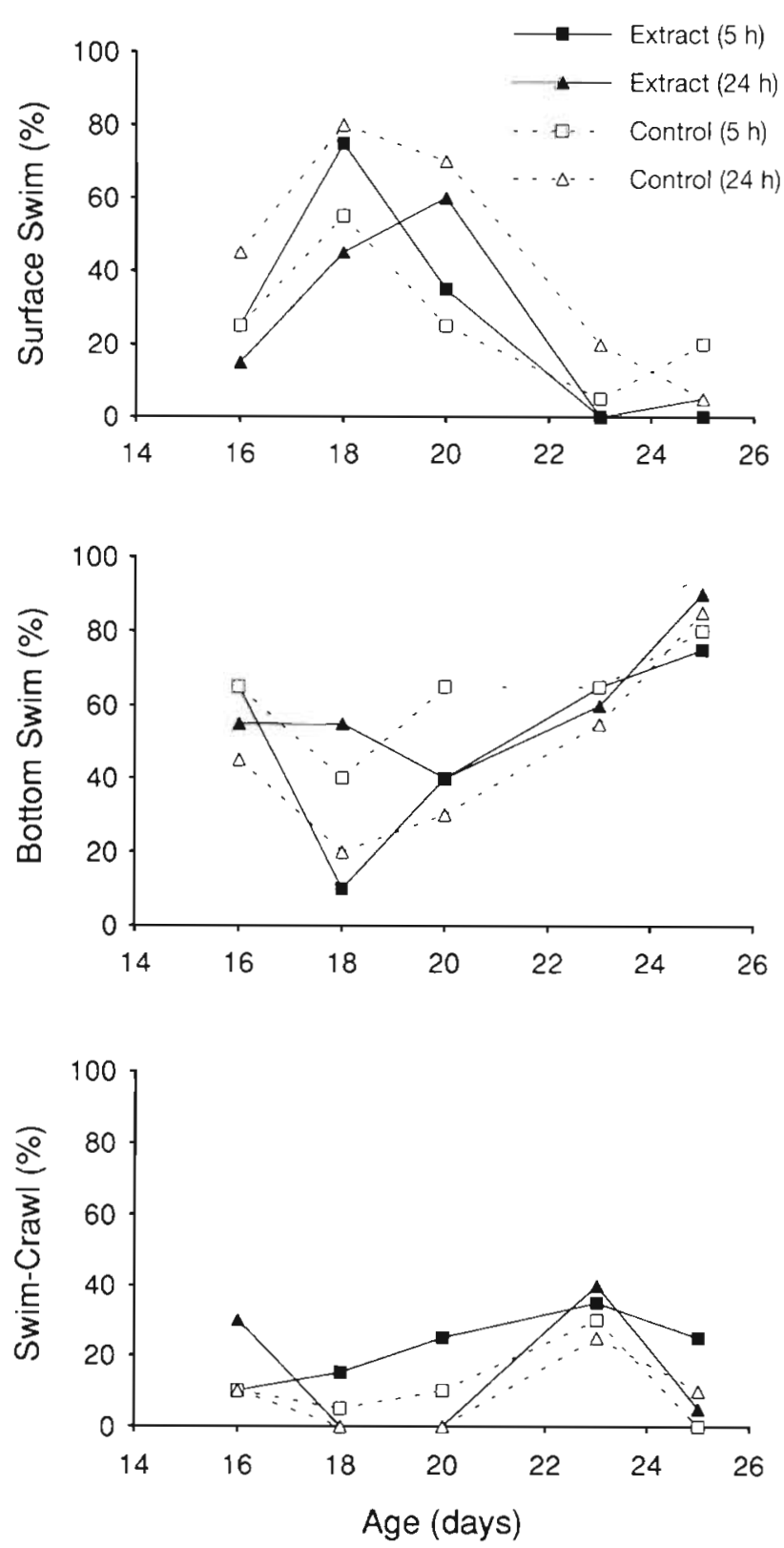

Fig. 2. Strombus gigas. Changes in swimming behavior as a function of larval age. Veligers $16 \mathrm{~d}$ post-hatch were precompetent, 18 to $23 \mathrm{~d}$ post-hatch were competent, and $25 \mathrm{~d}$ post-hatch were postcompetent. $\mathrm{n}=1$ larva per treatment, with 20 replicates per treatment

centage metamorphosis observed for the extract and detritus cues on Day 23 (Fig. 1). Also, 30\% of Day 23 larvae in the swim-crawl stage underwent metamorphosis in the low extract concentration of Laurencia poitei.

There were no consistent differences between the 5 and $21 \mathrm{~h}$ observations. The larvae were located in similar positions in the seawater and extract containers throughout the $24 \mathrm{~h}$ experiment (Fig. 2); however, differences were observed in swimming behavior. Larvae in the extract hovered close to the sides of the containers and as they became older they became stationary on the bottom with their lobes extended. The larvae in seawater swam actively throughout the container on all experimental dates. Regardless of treatment (seawater or extract) some larvae were observed bouncing just below the water surface or twirling near the bottom of the container. These movement patterns became more pronounced in older larvae (Days 20 to 25).

\section{DISCUSSION}

Termination of the precompetence period for larvae of Strombus gigas was first recognized as an ontogenetic change in locomotory behavior. The larva shifted from a swimming to a swimming and crawling mode, using its propodium and adult opercular claw to glide or leap across the substrate surface and its velar lobes to swim. Berg (1972) described a similar behavior in competent larvae of Strombus maculatus, noting this as a general characteristic among the superfamily Strombacea. The swim-crawl stage has been observed up to $7 \mathrm{~d}$ prior to metamorphosis for veligers of $S$. gigas (D'Asaro 1965, Brownell 1977) and could be considered the settlement phase. Conch larvae may use the swim-crawl mode to test substrate for metamorphosis and resume swimming if inappropriate habitat was detected.

In this study the mean shell length of larvae of Strombus gigas that successfully metamorphosed was $1125 \pm 71 \mu \mathrm{m} \mathrm{SD}$; this coincides with hatchery culture data (Ballentine \& Appeldoorn 1983, Davis et al. 1990 1993). Size can only be used as a relative indicator of competence, because there was no significant difference in shell length between larvae and newly metamorphosed juveniles at Days 20 and 23. Other factors controlling metamorphosis, such as physiological readiness and inducer thresholds, may vary for individuals of the same size class. This was the case for larvae of the opisthobranch Phestilla sibogae exposed to the coral inducer Porites compressa (Hadfield 1977) and also for the gastropod Crepidula fornicata exposed to $\mathrm{KCl}$ (Pechenik \& Heyman 1987, Pechenik \& Gee 1993). Therefore, a combination of age, size, behavior, and morphological differentiation must be used as indicators of competence for larvae of $S$. gigas.

Precompetent larvae of Strombus gigas have only orange pigmentation on the propodium and larval operculum; this is based on morphological observations in this study and from prior culturing experience (Davis 1993, Davis et al. 1993). In this study, Day 16 larvae with only orange pigmentation were competent 
to undergo metamorphosis when exposed to highly concentrated extract of Laurencia poitei. However, these newly metamorphosed juveniles had emaciated bodies and were inactive, making them unfit for juvenile survival. Observations of these larvae prior to metamorphosis indicated that they were not emaciated, so these larvae may have had inadequate energy reserves to undergo the physiological and morphological changes required during metamorphosis. Given that $16 \mathrm{~d}$ old larvae did not respond to the natural inducer in the laboratory, it is unlikely that they would have metamorphosed in the field. Pechenik \& Gee (1993) suggested a similar situation for larvae of the gastropod Crepidula fornicata: they were competent to respond to the artificial cue, excess $\mathrm{K}^{+}$, before they were competent to respond to the natural cue, adultconditioned seawater.

Onset of competence for larvae of Strombus gigas was noted when pigmentation on larval operculum changed from orange to dark green (Day 18). Throughout the competence period (Days 18 to 25) green pigmentation increased on the propodium and larval operculum. Sensitivity to extract of Laurencia poitei (10 $\mathrm{g}$ wet wt algal fronds $\mathrm{l}^{-1}$ seawater) and seagrass detritus also increased with development of green pigmentation, as did metamorphic response which peaked on Day 23. This sensitivity was further noticed during behavioral observations: $30 \%$ of the older larvae (Day 23) metamorphosed in low extract concentration of $L$. poitei $\left(1.0 \mathrm{~g}\right.$ wet wt algal fronds $\mathrm{l}^{-1}$ seawater). This responsiveness or sensitivity to inducers with increasing larval development was also observed for the opisthobranch Phestilla sibogae when exposed to Porites compress (Hadfield 1977), and larvae of the gastropod Haliotis rufescens when exposed to GABA (Barlow 1990).

By Day 25 it appeared that the competence period was over, because metamorphic response of Strombus gigas larvae decreased dramatically. These larvae had morphological features indicating competence (i.e. green pigmentation on propodium), but most of them did not metamorphose. This sudden change from competence to loss of competence could be related to the concept that larval life is characterized by a series of developmental events which lead to a genetically fixed larval endpoint as seen with the gastropod Crepidula fornicata (Pechenik 1984). Similar to C. fornicata, larvae of $S$. gigas continued to grow and morphologically differentiate during the competence period. When there is no developmental arrest during the competence period, time to locate an optimal settlement habitat becomes increasingly urgent before nutritional reserves are depleted (Miller \& Hadfield 1990, Pechenik et al. 1993).

Lack of nutritional reserves may have prevented larvae of Strombus gigas from metamorphosing suc- cessfully after Day 25. By this time the velar lobes had decreased in size; this resorption of the feeding structures before metamorphosis could debilitate the ciliaryfeeding larva. Furthermore, D'Asaro (1965) observed that larvae of $S$. gigas in the swim-crawl stage develop a buccal mass in preparation for benthic feeding. This is similar to the larvae of the lecithotrophic gastropod Haliotis rufescens, which develop their radular feeding apparatus during delay of metamorphosis to enable them to feed immediately upon settling (Barlow \& Truman 1992). It appears that larvae of $S$. gigas become less efficient at feeding in the water column if they have not metamorphosed before the development of the buccal mass and the decrease in size of the velar lobes. This is analogous to nauplii and cyprid larvae of the barnacle Balanus amphitrite (Pechenik et al. 1993) and larvae of the mussel Mytilus edulis (Bayne 1965, Pechenik et al. 1990). These species feed until they are morphologically incapable of feeding, at which time they must settle or die.

In this laboratory study, larvae of Strombus gigas had a precompetence period of $18 \mathrm{~d}$ and a competence period of $6 \mathrm{~d}$ at 28 to $30^{\circ} \mathrm{C}$. The short competence period in $S$. gigas is a unique developmental history among planktotrophic larvae. Most planktotrophic larvae have a competence period equal to or longer than the precompetence period; they disperse great distances in the precompetence period and require a long competence period to allow them to arrive in suitable settlement habitat (Jackson \& Strathmann 1981). This long competence period is possible because most planktotrophic larvae feed throughout their larval cycle and do not suffer nutritional stress (Pechenik 1990).

Even though larvae of Strombus gigas feed during their competence period, they are limited to a short competence period and a relatively brief period to delay metamorphosis. Short competence periods are usually associated with lecithitrophic (non-feeding) larvae, where nutritional requirements predicate the need for them to settle early after the onset of competence. This is the case in larvae of the polychaete Capitella sp. I which loses the ability to metamorphosis after $72 \mathrm{~h}$ (Pechenik \& Cerulli 1991). Planulae of the coral Alcyonium siderium show decreasing ability to metamorphose in $10 \mathrm{~d}$ at 11 to $13^{\circ} \mathrm{C}$ (Sebens 1983), and larvae of the bivalve Lyrodus edicellatus can delay metamorphosis for only $1 \mathrm{wk}$ (Turner \& Johnson 1971).

Based on the theory that duration of competence period or length of time a larva can delay metamorphosis is correlated with the specificity of habitat requirements (Crisp 1974, Pechenik 1980), larvae of Strombus gigas with a short competence period should metamorphose in response to a broad range of environmental cues. Recent studies confirmed larvae of 
$S$ gigas metamorphose in response to a variety of benthic cues found in juvenile conch habitats ( $M$. Davis \& A. W. Stoner unpubl.). Because these cues exist over a broad range of shallow marine environments, the conch larvae may need only a short competence period to locate suitable settlement habitat for growth and survival to juvenile and adult stages.

Acknowledgements. This research was supported by a grant from the National Undersea Research Program, NOAA (U.S. Department of Commerce), to the Caribbean Marine Research Center. The author thanks A. W. Stoner and M. Ray for assisting in design of the experiments. Many thanks go to the Caicos Conch Farm for the use of their veligers and laboratory space. S. Mann and C. Dyer were especially helpful in the day-to-day logistics and set-up of the experiments. M. G. Hadfield, J. A. Pechenik, A. W. Stoner and 3 anonymous reviewers contributed valuable comments on the manuscript.

\section{LITERATURE CITED}

Ballantine, D. L., Appeldoorn, R. A. (1983). Queen conch culture and future prospects in Puerto Rico. Proc. Gulf Caribb. Fish. Inst. 35: 57-63

Barlow, L. A. (1990). Electrophysiological and behavioral responses of larvae of the red abalone (Haliotis rufescens) to settlement-inducing substances. Bull. mar. Sci. 46: $537-554$

Barlow, L. A., Truman, J. W. (1992). Patterns of serotonin and SCP immunoreactivity during metamorphosis of the nervous system of the red abalone, Haliotis rufescens. J. Neurobiol. 23: 829-844

Bayne, B. L. (1965). Growth and delay of metamorphosis of the larvae of Mytilus edulis (L.). Ophelia 2: 1-47

Berg, C. J. Jr (1972). Ontogeny of the behavior of Stombus maculatus (Gastropoda: Strombidae). Am. Zool. 12: $427-443$

Brownell, W. N. (1977). Reproduction, laboratory culture, and growth of Strombus gigas, S. costatus and S. pugilus in Los Roques, Venezuela. Bull. mar. Sci. 27: 668-680

Burke, R. D. (1983). The induction of metamorphosis of marine invertebrate larvae: stimulus and response. Can. J. Zool. 61. 1701-1719

Coon, S. L., Fitt, W. K., Bonar, D. B. (1990). Competence and delay of metamorphosis in the Pacific oyster Crassostrea gigas. Mar. Biol. 106: 379-387

Crisp. D. J. (1974). Factors influencing the settlement of marine invertebrate larvae. In: Grant, P. T., Mackie, A. M. (eds.) Chemoreception in marine organisms. Academic Press, New York, p. 177-265

D'Asaro, C. N. (1965). Organogenesis, development, and metamorphosis in the queen conch, Strombus gigas, with notes on breeding habits. Bull. mar. Sci. 15:359-416

Davis, M. (1993). Mariculture techniques for queen conch (Strombus gigas Linne): egg mass to juvenile stage. In: Appeldoorn, R. S., Rodriguez, B. (eds.) Queen conch biology, fisheries, and mariculture. Fundacion Cientifica, Los Roques, Caracas, Venezuela

Davis, M., Bolton, C. A., Stoner, A. W. (1993). A comparison of larval development, growth, and shell morphology in three Caribbean Strombus species. Veliger 36: 236-244

Davis, M., Hesse, C., Hodgkins, G. (1987). Commercial hatchery produced queen conch, Strombus gigas, seed for the research and grow-out market. Proc. Gulf Caribb. Fish. Inst. 38: 326-335

Davis, M., Heyman, W. D., Harvey, W., Withstandley, C. A. (1990). A comparison of two inducers, $\mathrm{KCl}$ and Laurencia extracts, and techniques for the commercial scale induction of metamorphosis in queen conch Strombus gigas Linnaeus, 1758 larvae. J. Shellfish Res. 9: 67-73

Day, R. W., Quinn, G. P. (1989). Comparisons of treatments after an analysis of variance in ecology. Ecol. Monogr. 59: $433-463$

Hadfield, M. G. (1977). Chemical interactions in larval settling of marine gastropod. In: Faulkner, D. J., Fenical, W. H. (eds.) Marine natural products chemistry. Plenum, New York, p. 403-413

Hadfield, M. G. (1978). Metamorphosis in marine molluscan larvae: an analysis of stimulus and response. In: Chia, F. S., Rice, M. E. (eds.) Settlement and metamorphosis of marine invertebrate larvae. Elsevier North-Holland, New York, p. 165-175

Jackson, G. A., Strathmann, R. R. (1981). Larval mortality from offshore mixing as a link between precompetent and competent periods of development. Am. Nat. 118: 16-26

Laughlin, R. A., Weil, E. (1983). Queen conch mariculture and restoration in the Archipielago de Los Roques. Proc. Gulf Caribb. Fish. Inst. 35: 64-72

Mianmanus, R. T (1988). Induction of settlement and metamorphosis in larvae of Aplysia brasiliana and Strombus gigas (Mollusca: Gastropoda). Ph.D. dissertation, University of Miami

Miller, S. E., Hadfield, M. G. (1990). Developmental arrest during larval life and life-span extension in a marine mollusc. Science 248: 356-358

Morse, D. E., Hooker, N., Duncan, H., Jensen, L. (1979). $\gamma$-Aminobutyric acid, a neurotransmitter, induces planktonic abalone larvae to settle and begin metamorphosis. Science 204: $407-410$

Pawlik, J. R. (1992). Chemical ecology of the settlement of benthic marine invertebrates. Oceanogr. mar. Biol. A. Rev. 30: $273-335$

Pechenik, J. A. (1980). Growth and energy balance during the larval lives of three prosobranch gastropods. J. exp. mar. Biol. Ecol. 44: 1-28

Pechenik, J. A. (1984). The relationship between temperature, growth rate, and duration of planktonic life for larvae of the gastropod Crepidula fornicata (L.). J. exp. mar. Biol. Ecol. 74: 241-257

Pechenik, J. A. (1985). Delayed metamorphosis of marine molluscan larvae: current status and directions for future research. Am. malac. Bull., Spec. edn 1.85-91

Pechenik, J. A. (1990). Delayed metamorphosis by larvae of benthic marine invertebrates: does it occur? Is there a price to pay? Ophelia 32: 63-94

Pechenik, J. A., Cerulli, T R. (1991). Influence of delayed metamorphosis on survival, growth, and reproduction of the marine polychaete Capitella sp. I. J. exp. mar Biol. Ecol. 151: 17-27

Pechenik, J. A., Eyster, L. S., Widdows, J., Bayne, B. L. (1990). The influence of food concentration and temperature on growth and morphological differentiation of blue mussel Mytilus edulis L. larvae. J. exp. mar. Biol. Ecol. 136: $47-64$

Pechenik, J. A., Gee, C. C. (1993). Onset of metamorphic competence in larvae of the gastropod Crepidula fornicata, judged by a natural and an artificial cue. J. exp. mar. Biol. Ecol. 167: 59-72

Pechenik, J. A., Heyman, W. D. (1987). Using $\mathrm{KCl}$ to determine size at competence for larvae of the marine gastro- 
pod Crepidula fornicata (L.). J. exp mar. Biol. Ecol. 112: $27-38$

Pechenik, J. A., Lima, G. (1984). Relationship between growth, differentiation, and length of larval life for individually reared larvae of the marine gastropod, Crepidula fornicata. Biol. Bull. 166: 537-549

Pechenik, J. A., Rittschof, D., Schmidt, A. R. (1993). Influence of delayed metamorphosis on survival and growth of juvenile barnacles Balanus amphitrite. Mar. Biol. 115: 287-294

Scheltema, R. S. (1971). Larval dispersal as a means of genetic exchange between geographically separated populations of shallow-water benthic marine gastropods. Biol. Bull. 10: $284-322$

Scheltema, R. S. (1974). Biological interactions determining larval settlement of marine invertebrates. Thalassia jugosl. 10: $263-296$

This article was presented by J. Pawlik, Wilmington,

N. Carolina, USA
Sebens, K. P. (1983). Settlement and metamorphosis of a temperate soft-coral larva (Alcyonium siderium Verrill): induction by crustose algae. Biol. Bull. 165: 286-304

Siddall, S. E. (1983). Biological and economic outlook for hatchery production of queen conch. Proc. Gulf Caribb. Fish. Inst. 35: 46-53

Turner, R. D., Johnson, A. C. (1971). Biology of marine woodboring molluscs. In: Jones, E. B. G., Eltringham, S. K. (eds.) Marine borers, fungi, and fouling organisms of wood. Organization for Economic Cooperation and Development, Paris, p. 259-301

Zimmerman, K. M., Pechenik, J. A. (1991). How do temperature and salinity affect relative rates of growth, morphological differentiation, and time to metamorphic competence in larvae of the marine gastropod Crepidula plana? Biol. Bull. 180: 372-386

Manuscript first received: June 15, 1993

Revised version accepted: October 26, 1993 